\title{
PRESERVING THE NON-PRESERVABLE GEOHERITAGE OF THE ALIAKMON RIVER: A CASE STUDY IN GEO- EDUCATION LEADING TO CUTTING-EDGE SCIENCE
}

\author{
Rassios A. ${ }^{1}$, Grieco G. ${ }^{2}$, Batsi A. ${ }^{3}$, Myhill R. ${ }^{4}$ and Ghikas D. ${ }^{5}$ \\ ${ }^{1}$ Institute of Geology and Mineral Exploration, Regional Office of West Macedonia, Lefkovrisi - \\ Kozani, 50100 Greece, rassannie@gmail.com \\ ${ }^{2}$ Scienze della Terra "A. Desio," Università degli Studi di Milano, Via Botticelli, 23 Milano, Italy, \\ giovanni.grieco@unimi.it \\ ${ }^{3}$ Aim. Veaki 12, Kozani 50131, Greece, annampatsi@gmail.com \\ ${ }^{4}$ Bayerisches Geoinstitut, Universitätsstraße 30, 95447 Bayreuth myhill, bob@gmail.com \\ ${ }^{5}$ Geopark Grevena-Tethys, TEI Grevena 51100, Greece, notconstandina@hotmail.com
}

\begin{abstract}
The initial documentation of an ophiolite as oceanic lithosphere and the significance of an ophiolite's basal sole in its emplacement were based on the research of E. Moores (1969) and J. Zimmerman (1968) at the Vourinos Ophiolite, Greece: their work became a lynch-pin in the establishment of plate tectonic theory. Key localities of their research were located along the Aliakmon River Valley between Ilariona Monastery and the village of Panayia. This same area has since been flooded (2012) with the construction of a new hydroelectric reservoir. There was no option for "saving" these sites of the birth of plate tectonic theory: what could be done to preserve their geoheritage? Between 2005 and 2008, the Institute of Geology and Mineral Exploration, with funding provided from the Public Power Corporation, sponsored geo-education to provide a "last chance" of geologic documentation of the Aliakmon Valley. In a three year period, over 60 international student and professorial-level researchers participated in the project. 37 Senior Theses were produced and 6 masters' dissertations. The greatest achievement of the program was the revitalization of the Aliakmon data base within current, cutting-edge scientific models.
\end{abstract}

Keywords: Geoheritage, Geoeducation, Aliakmon, Geopark.

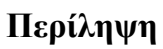

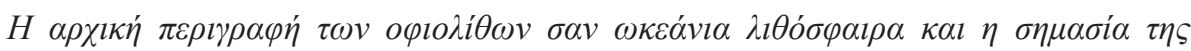

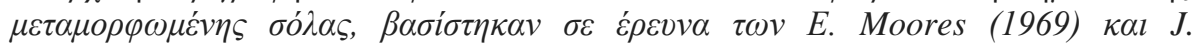

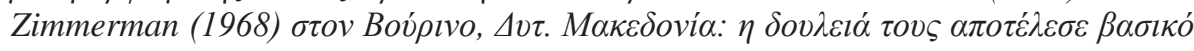

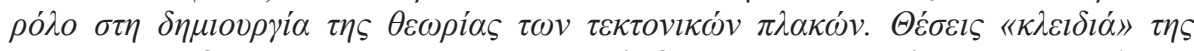

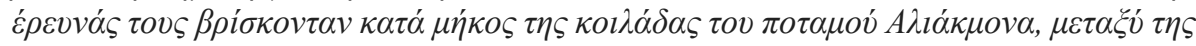

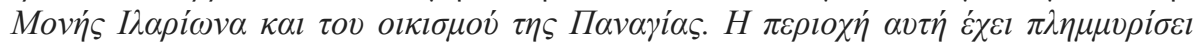

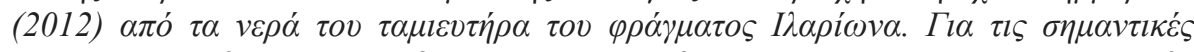

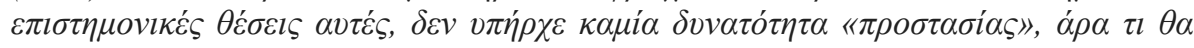

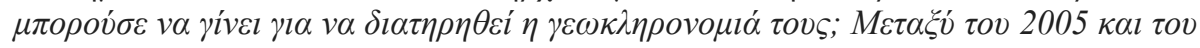




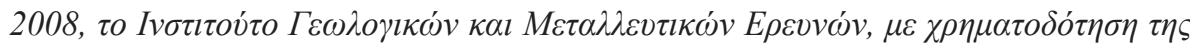

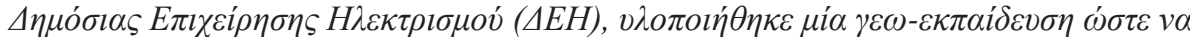

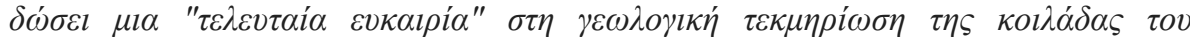

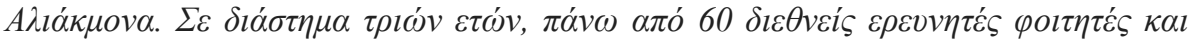

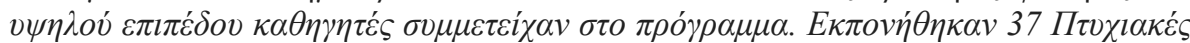

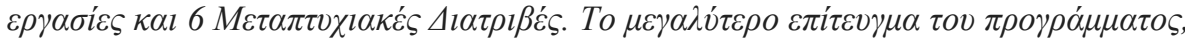

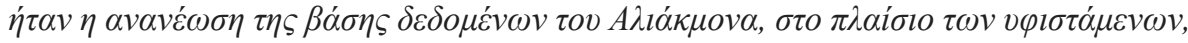

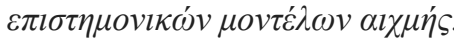

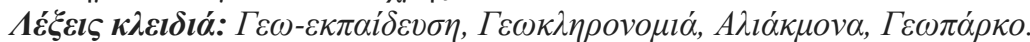

\section{Introduction}

There are times when geoheritage sites simply cannot be preserved. The Public Power Corporation of Greece (PPC - $\triangle \mathrm{EH}$ ) planned the construction of a major hydroelectric reservoir at the site of Ilariona (West Macedonia) as long ago as the 1990's. This dam would flood sections of the Aliakmon River Valley past the Zavordas Monastery and towards the Grevena villages of Dimitra and Karperon (Figure 1). The benefits in low-cost power supply and additional reserves for irrigation would provide invaluable national and regional benefits. Construction began in 2003, alongside studies documenting the archaeologic and bio-diversity of the valley. Geotechnical studies for hydrogeological assessment of the impound basin were carried out by the PPC, but the original geologic study was considered complete based on its inclusion in 1:50,000 scale map sheets of IGME, and the existence of academic research dating from the 1960's.

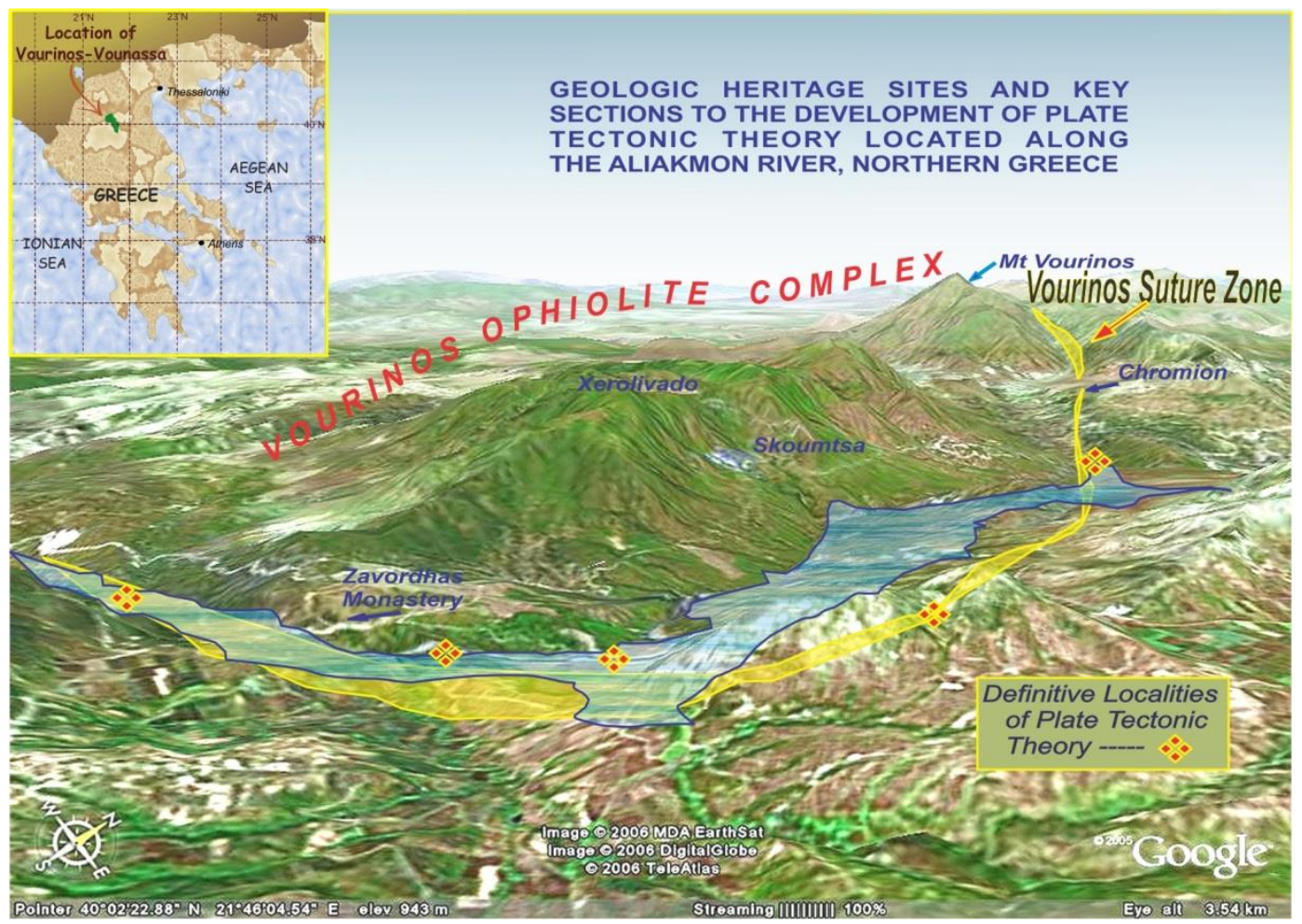

Figure 1 - Location of Geoheritage Sites of the Vourinos Suture Zone along the Aliakmon River Valley, and water-level of new Lake Ilariona. Inset: Location of Study Area in Greece.

These original studies of the Aliakmon Valley were made with the knowledge-base of the 1960's. Today's use of tectonic-kinematic indicators was unknown at the time, as were mineralogicalanalytical methods of reconstructing temperature-pressure evolution. The plate tectonic model is 
now a geological paradigm, based in part on these original studies of the Aliakmon Valley. We approached the PPC with the proposal to review the valley's tectonic sites using a contemporary science base, and to document its geo-historic features with more modern mapping (GIS-based) and photographic techniques. We were aware that this would be the last opportunity to survey these critical localities. What we did not expect were results that added to a "cutting edge" scientific view of the tectonic processes of ophiolitic emplacement and important new descriptions leading to the interpretation of the region as the "Birth of Europe".

\section{Geoheritage of the Aliakmon Valley}

The historical nature of studies of the area date to the pioneering study by Jan Brunn during the late 1930's, published within his doctoral thesis in 1956 (Brunn, 1956). Brunn was impressed by the ophiolitic contact exposed in the river valley and indeed, later stated (pers. comm.) that he thought this to be the most important ophiolitic contact ever located. Brunn, however, was working in the era of the geosynclinal paradigm; his study indeed made important contributions to the "geosynclinal model" of the Tethyan-related sedimentation, and was so recognized by Aubouin (1965). However, as elsewhere, the geosynclinal model did not explain the presence of ophiolitic complexes in general, nor specifically the Vourinos contact (Figure 2).
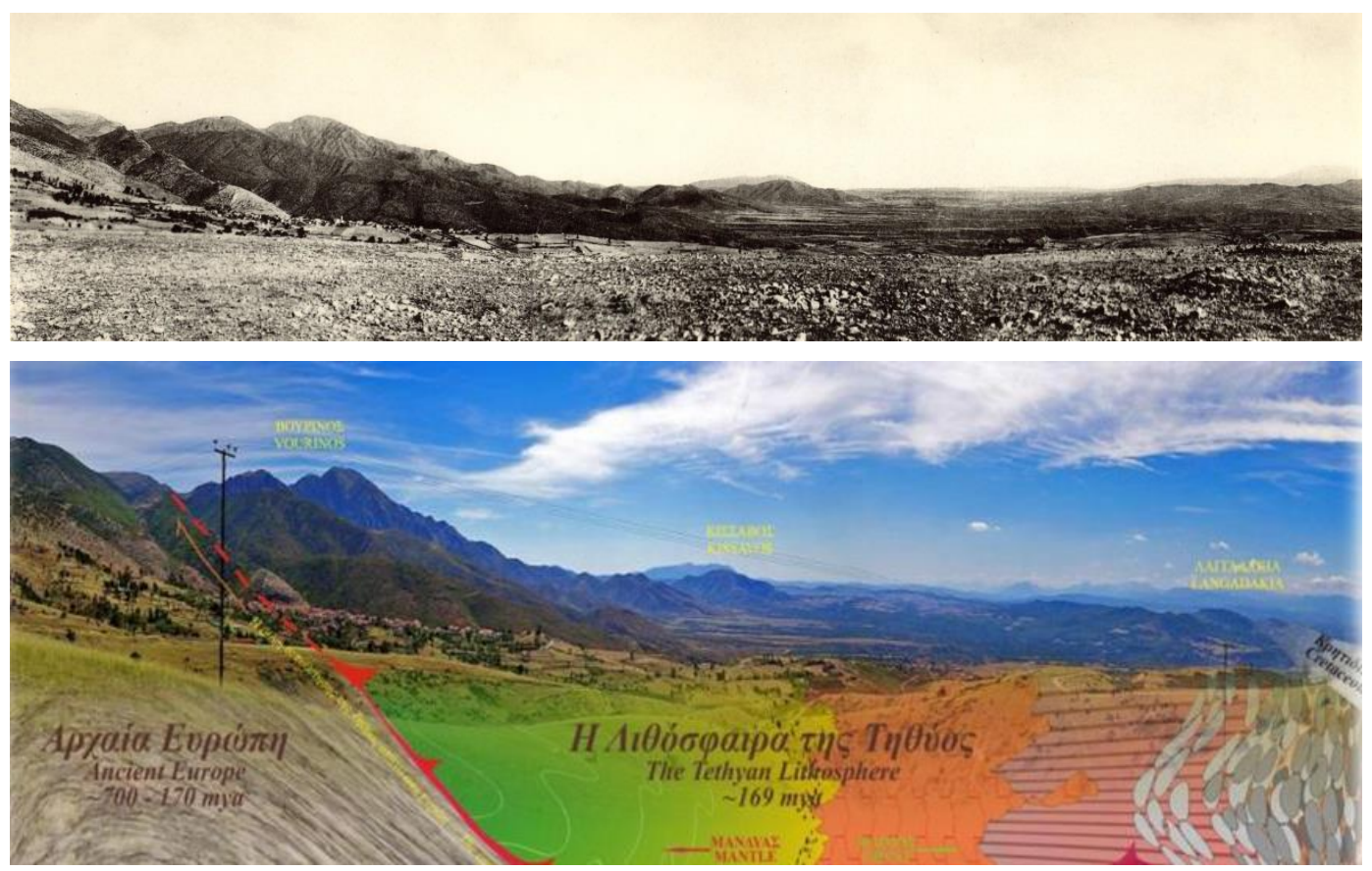

Figure 2 - Above: Brunn's Panorama of the Vourinos Ophiolite (1938). Below: the "same" Panorama (2010) with the lithospheric interpretation of Moores (1969).

Brunn made a step forward towards the plate tectonic model when he recognized that the descriptions of rocks of the mid-Atlantic ridge by Ewing (in Heezen et al., 1959) were alike the rocks of Vourinos (Brunn, 1959). Brunn speculated a similar mode of petrologic origin, if not an oceanic ridge setting.

At a time when plate tectonic theory was not much more than speculation, John Maxwell of Princeton viewed a copy of Brunn's thesis, and was impressed by the apparent complete nature of the ophiolitic section of Vourinos (Moores, 2003). Thus, Princeton researchers Moores and Zimmerman began an investigation of the Brunn section. In short, their investigation gave the following results and led to further "cutting edge" (now considered pioneering) research: 
- Moores described and documented Vourinos as a potential oceanic lithospheric analogy with an intact internal section extending from earth's upper mantle through an oceanic crust to sub-sea sedimentary deposits (Moores, 1969).

- The metamorphic sole of the ophiolite onto Pelagonian and intercalated marginal sediments (Figure 3) is the first (Zimmerman, 1968) to first document the reverse metamorphic zonation typical of ophiolite sole contacts.

- The combination of the description of the ophiolitic lithosphere section by Moores and the sole description by Zimmerman established that ophiolites indeed are emplaced remnants of oceanic lithosphere, a key part of plate tectonic theory.

- In subsequent years, their results lead to the Vourinos sole as among the first to be dated using pioneering amphibolite radiogenic procedures (Spray et al., 1980); this study was recently modernized using current methodology of analyses of garnet amphibolite by an associate of the Aliakmon Program (Myhill, 2008).

It is perhaps a tribute to Moores that, ever since its initial documentation, representative sketches of oceanic lithosphere in general geologic literature are based on the Vourinos ophiolitic section.

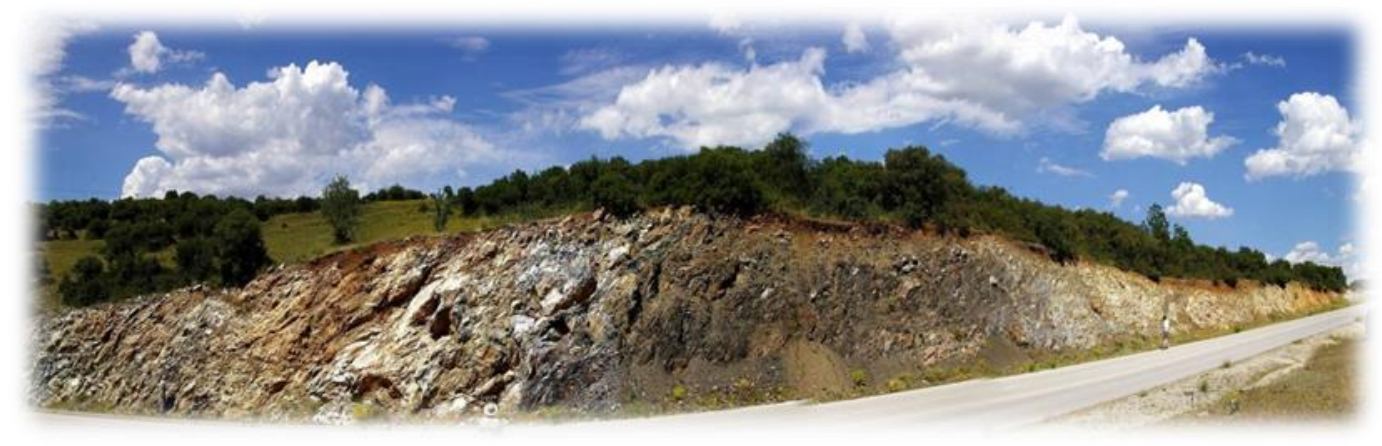

Figure 3 - A road-cut occurrence of the Vourinos Sole over Jurassic meta-sediments of the Ayios Nikolas formation. Serpentinised harzburgite tectonite at the left (west) of the photo: black section is amphibolite, then grading to greenschist and zeolite metamorphism to the right of the section. Photo taken between Panayia Village and Zavordas Monastery.

\section{Documentation of the Threatened Sites}

The problem of geoheritage preservation along the Aliakmon River then turned to methodology in the following sense:

- How to document the river valley using "modern" geologic techniques?

- How to pass the geoheritage to those who should inherit this information?

At the time of the initial descriptions of the Aliakmon Valley sole formations, available topographic maps were crude, and geologic field description depended on compass and measured sections that lacked GPS technologies. Structural geology had not advanced to the stage of interpretation of kinematic indicators; the deformation model accompanying thrust-related motions had yet to be studied; metamorphic petrology had yet to utilize applicable radiogenic dating techniques. Photographs of the river valley in the literature were scarce and poor in quality.

What was needed to document and pass on the geoheritage was determined to be detailed mapping analyses (using digital methodology) and the opportunity for young scientists to visit and understand the sites. As such, an invitation to participate in the "last chance" to study these sites was answered by more than sixty geology students and researchers; these came to the area in the years 2005 - 2008, and each devoted at least a month to their study. Participants came from the following universities: Cambridge (England), Milan (Italy), Cologne (Germany), Edinburgh (Scotland), Thessaloniki 
(Greece), Athens (Greece), Miami (Ohio - USA), Beloit (Wisconsin-USA), Utrecht (Holland), Cinncinnati - USA, Colgate - USA, and several others with short visits. Each participant was given:

- Access to otherwise inaccessible original studies of the valley including those of Brunn, Moores, and Zimmerman, as well as to European-Greek studies (Wright, 1986 among others) conducted within I.G.M.E.

- 1:5000 scale topographic maps of the area

- Access to existing microscopic petrographic collections

- A two-day preliminary training field trip within the Vourinos Ophiolite and Vounassa Metamorphic Section surveying petrologic and tectonic diversity.

After this period, a "simplistic" group project carried out to supplement education in petrologic identification included "cobble counts." The now-flooded riverbed of the Aliakmon is covered by a Holocene conglomerate deposit derived from surrounding rocks and older conglomerate deposits. At each study site, a "grid" was laid out of $100 \mathrm{~m}^{2}$ in area, with cobbles collected at every meter intersection. Their petrology, size, and angularities were recorded. In addition to educational goals for the researchers, these cobble counts are the only ones ever done within the conglomerate formation along the Aliakmon Valley. Even such simple studies (as for the two examples of Figure 4) raise basic questions such as: i. Where is the source of the abundant gabbro cobbles when gabbro is not present in the adjacent ophiolitic region, and ii. What explains the major variation in lithologic types between two sites so closely located (less than $3 \mathrm{~km}$ apart).
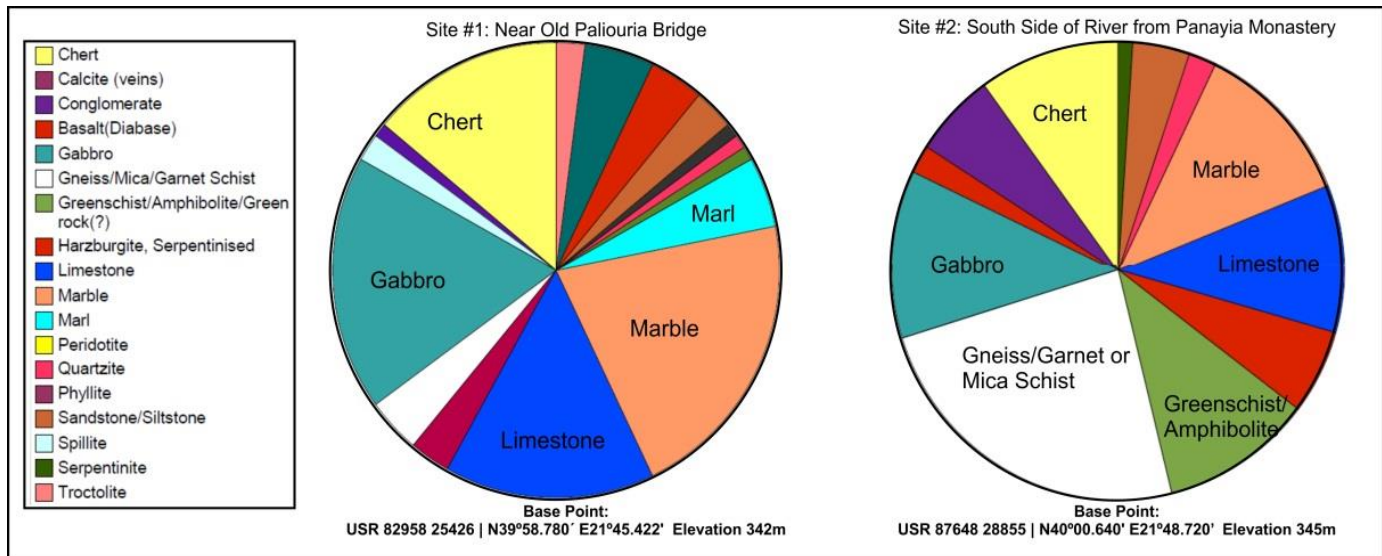

Figure 4 - Representative Pi diagrams of Cobble Counts from recent deposits on the Aliakmon Riverbed, now under the waters of the new Ilariona Lake (compiled by V. Lau).

In the course of their individual mapping projects, each participant was asked to "collect" ten rock samples with corresponding GPS location consisting of both representative and unusual lithologictectonic examples from the part of the river to be flooded. This has generated a study collection to be curated and made accessible for future geoscientists including over 500 samples. The collection is stored in Deskati, Greece, at the Geopark Grevena-Tethys Information Center.

Mapping: Depending on the educational level and priorities of students and researchers, mapping included classic stratigraphic analyses, structural analyses, and back-up petrography. These series of digital 1:5000 scale maps comprise the underpinning of the documentation of the now-flooded river section. The majority of the maps cover the "core" area of the program, the river section between the Zavordas Monastery and Panayia Village; several extend to the region of Frourio Village to the east where the ophiolitic sole extends from the Aliakmon and corresponds to an amphibolite/garnet amphibolite zone less than a meter in width; some projects concentrated on the structure from the Aliakmon sole zone into the Pelagonian complex, with emphasis on the nature of 
the deformation to the Triassic metasedimentary section. Several continuing researchers, returning over several summer sessions, documented structures corresponding to "rift valley" formation in the Pelagonian massif.

\section{Results: A "new" documentation of "old" Geoheritage}

Figure 5 displays four of the more than forty maps produced with this study. To say the least, each student/researcher saw unique features within the study area. In addition to details of the sole formation itself, some of these observations are of important geologic significance and lead, or would have lead if time permitted further study before the area was flooded, to critical new insights. For examples (Figure 6): a. Cretaceous fossils were located for the first time in remnant limestone caps deposited onto the Pelagonian formations that could have proven essential in describing the late-Jurassic - Cretaceous emplacement geomorphology; b. Basaltic dikes were traced from the tectonic melange unit into the Triassic-Jurassic Pelagonian carbonate formation; c. Pillow lavas within the tectonic melange that were subsequently analysed showed they related to Pelagonian rifting, and that the Aliakmon emplacement zone included both ophiolitic emplacement and older initial rifting phenomena.

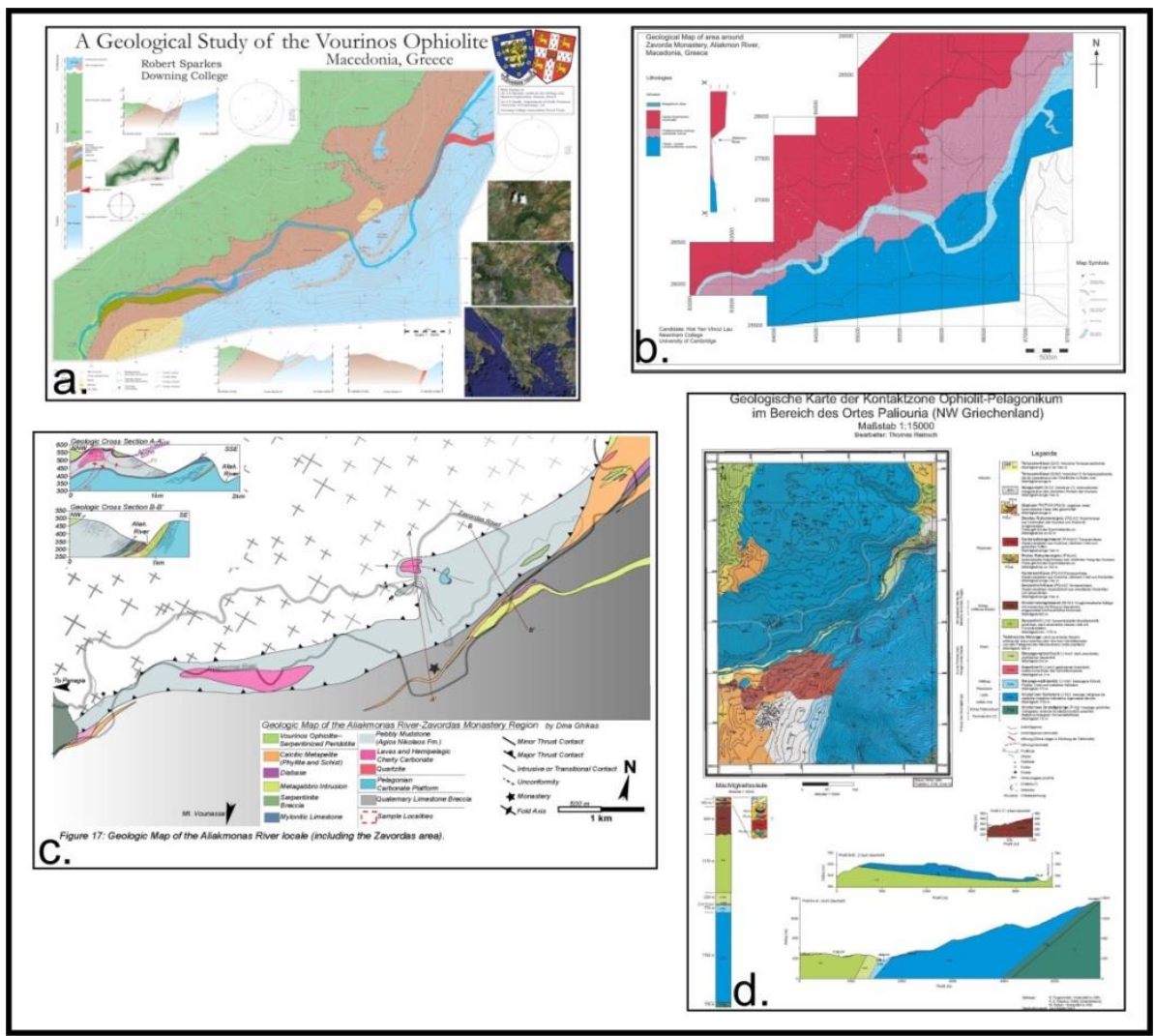

Figure 5 - Representative geologic maps of student-researchers participating in the Aliakmon River Legacy Project. a. Robert Sparks: Cambridge University. b. Vincci Lau: Cambridge University c. C. Ghikas, part of her Masters' from Miami University. d. Thomas Reinsch: University of Cologne. 


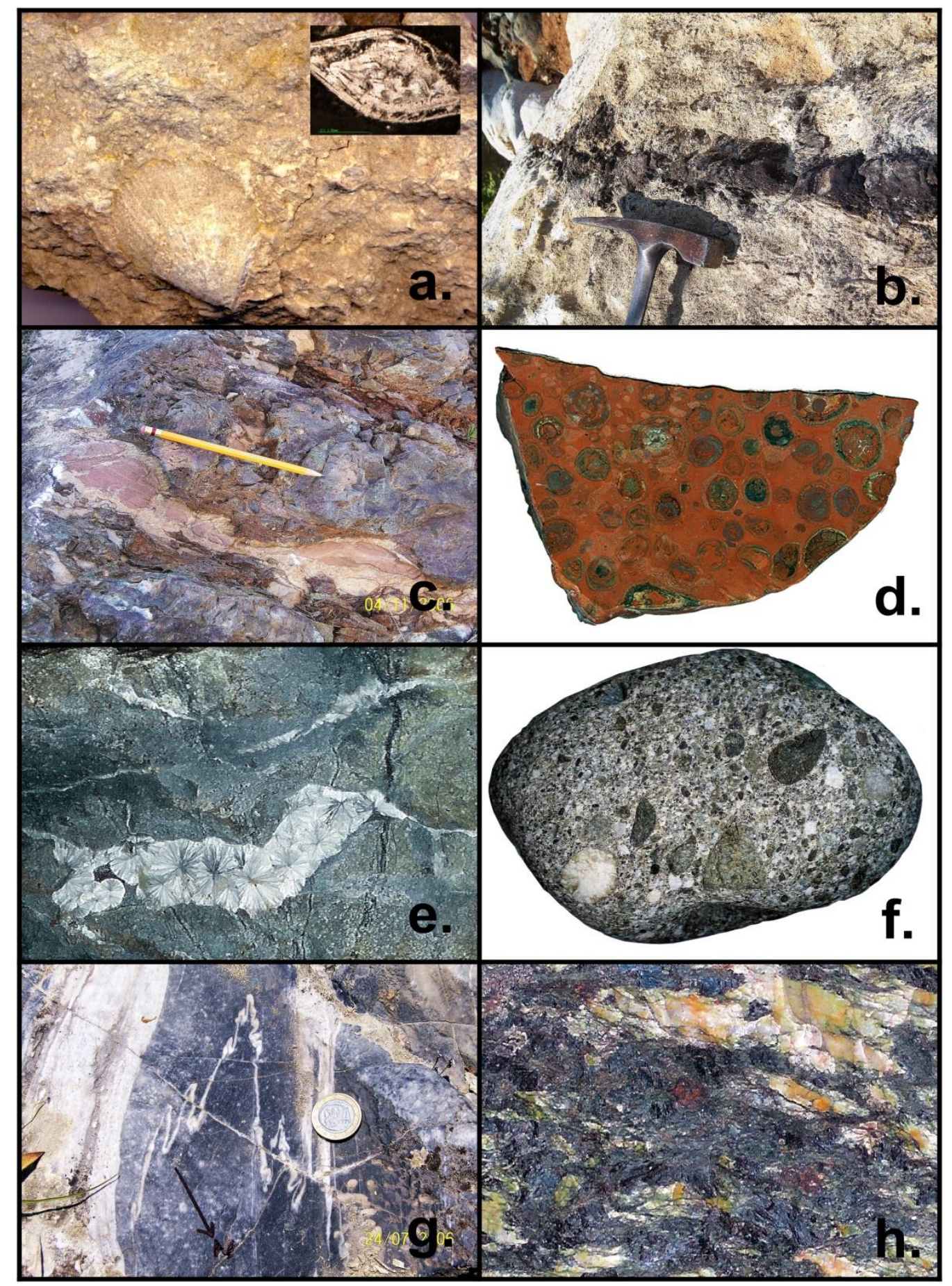

Figure 6 - Iconographic examples of original observations significant to interpretation of the tectonic evolution of the Aliakmon Valley: a. Cretaceous limestone fossils (M. Pedrotti); b.

Basalt dike in Tr-Jr limestone (Ghikas); c. Deformed rifting lavas and chert sediments

(Ghikas); d. Oolitic radiolarian chert (Ghikas); e. Zeolite veins (Myhill); f. Greywacke cobble; g. Intra-layer flow fold in Tr-Jr limestone; $h$. Garnet amphibolite from sole (Rassios, sample from student "rock rubbish" pile). 


\section{Results: Relevance to "Cutting-edge" Science of the Vourinos-Vounassa Ophiolite - Pelagonian Margin}

Some results of the Aliakmon Legacy Project were presented at the 2008 International Ophiolite Symposium (Rassios et al., 2008) which included the final conference field trip into the Aliakmon Valley. Much of the petrologic diversity of the section was presented in a "light" geological book by Rassios and the student researchers of the Legacy Project (Rassios and others, 2007). Both of these publications were written too early in the analytical phases of the project data to cover the comprehensive study of the section, nor does the present short paper allow a complete description of the immense data base generated during and as a result of the Aliakmon Legacy Project. However, a comparison of a short description of the Aliakmon Section predating the project can be compared to the current model, synthesized from the work of the Aliakmon Legacy research group:

\section{The Pre-Legacy Project Model (Rassios, 2004):}

"The Vourinos Ophiolite is emplaced over the Pelagonian Massif with 'bulldozed' foreland basin deposits entrapped in the collision zone and imprinted by metamorphism of the hot sole."

\section{The Current Model:}

The Vourinos Ophiolite is bounded along its north and south margins by transcurrent faults (Rassios and Moores, 2006) that accommodated complex compressional and strike-slip deformation as they displaced the ophiolite to the northeast (Ghikas, 2007). In the south-eastern extreme of the ophiolite, the fault is a wide zone, approaching a $\mathrm{km}$ in width, wherein the ophiolite-river section is overprinted by tectonic motions that record a thrust environment of NE-movement with a "splay" to SE as the thrust complex rotated its own margins/footwall as it moved forward. Garnets and amphiboles within the sole contact indicate formation at temperatures of $\sim 770^{\circ} \mathrm{C} \pm 100^{\circ} \mathrm{C}$ and pressures of $4 \pm 1 \mathrm{kbar}$, that is, the sole provenance would have been very close to the spreading system that created the ophiolite (Myhill, 2011). Within the Aliakmon River valley, kinematic motions are depicted ranging from ductile to brittle conditions. Along the Aliakmon River section, these movements merge the original ophiolitic emplacement over sediments of the Ayios Nikolas Formation (Naylor et al., 1976) with the transcurrent deformation: the fault - emplacement zone along the river section includes plastic deformation of host Pelagonian carbonates, intercalation of highly deformed and altered ophiolitic material, remnants of the garnet amphibolite/amphibolite ophiolitic sole, and preserves older (Triassic) rifting lavas and sedimentation dating from the break-up of Pelagonia. The river section is intruded by "leaks" of younger basalt and gabbro within the internal zone of the transcurrent fault, some extending into older Pelagonian country rock. The southernmost contact of the transcurrent fault formation parallels the extension of the Servian Fault along Mount Vounassa, implying that this massive variation in rock competency accounted for the fault's location. Thus, the transcurrent fault once exposed along the Aliakmon River section is demonstrated to comprise a major tectonic feature parasitically facilitating and recording over 200 million years of tectonic history of the Pelagonian - Tethyan margin.

\section{Final Statements:}

We feel that in addition to the primary goal of the project, some valuable lessons in geoheritage preservation were attained:

A re-investigation of a classic geological area brings new information and invites opportunities for research: for examples, researchers of the Legacy project also began new study of the chrome ore districts of the Vourinos Ophiolite leading to further investigation of the alteration processes of chrome spinels. This lead to reconstruction of the metamorphic history of the complex that shows that alteration $\mathrm{Cr}$-spinel, with formation of a Fe-chromite - Cr-clinochlore assemblage, can occur before ophiolite obduction (Grieco and Merlini, 2012). Recently, new cutting-edge studies by Zlatkin (Zlatkin et al., 2014) of zircon dating within the Pelagonian complex near the Aliakmon 
Legacy area, located the currently "oldest rocks in Greece" with zircons dated at 980 my.

The success of the Legacy Project has improved the scientific knowledge base sufficiently to justify inclusion of the Vounassa region within an aspiring Geopark (Geopark Grevena-Tethys); an educational program similar to that of the Legacy Project is planned for the Geopark region. Geoheritage is for future generations. It can allow new scientists to retrace the steps of those who made the initial discoveries of geologic paradigms and allow them to continue along the path towards new tectonic and petrogenetic innovation to the current paradigms.

Geoheritage aided in the advanced education of sixty up-and-coming geology students. These young scientists are now located around the globe and are, themselves, now respected international researchers. These students can be considered the core-group for passing onward the memory of these spectacular outcrops of the Aliakmon Geoheritage sites (Figure 7).

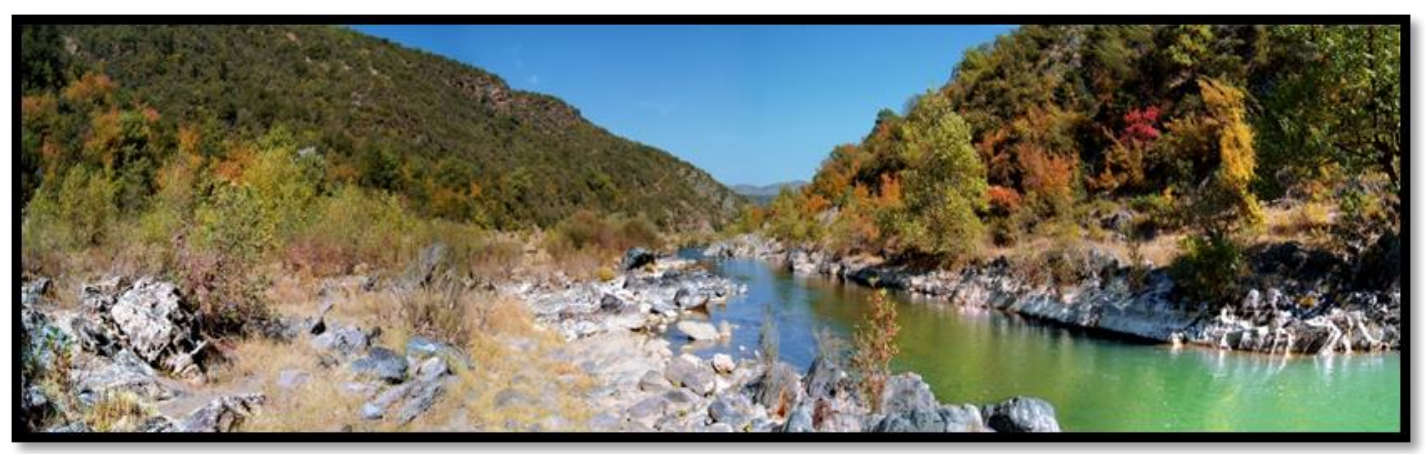

Figure 7 - A last view of the Aliakmon River Valley.

\section{Acknowledgments}

The Aliakmon Legacy Project was conducted as a non-profit program within the Institute of Geology and Mineral Exploration of Greece. Funding was provided by the Public Power Corporation of Greece, who are to be especially thanked for the positive outcome of the program. The researchers involved in addition to the authors of this paper include: Alan Smith, Alastair Robertson, Yildirim Dilek and ... sixty world-class geology students.

\section{References}

Aubouin, J., 1965. Geosynclines, Elsevier, 352 pp.

Brunn, J., 1956. Contribution a L'Étude Géologique du Pinde Septentrional et D'une Partie de la Macédoine occidentale, Ann. Geol. Pays. Hellen., 7, 1-358.

Brunn, J.H., 1959. La dorsale médio-atlantique et les épanchements ophiolitiques: Compte rendues sommaire des sciences de la Société géologique de France, 234-237.

Ghikas, C., 2007. Structure and Tectonics of a Subophiolitic Melange (Zavordas Melange) of the Vourinos Ophiolite (Greece) and Kinematics of Ophiolite Emplacement, MSc Thesis, Miami University, Ohio-USA, $121 \mathrm{pp}$.

Ghikas, C., Dilek, Y. and Rassios, A., 2010. Structure and Tectonics of Subophiolitic Mélanges in the Western Hellenides (Greece) and Implications for Ophiolitic Root Zones in the Balkans, EGU General Assembly 2010, held 2-7 May, 2010 in Vienna, Austria, 7282 pp.

Ghikas, C., Dilek, Y. and Rassios, A., 2010. Structure and tectonics of subophiolitic mélanges in the western Hellenides (Greece): implications for ophiolite emplacement tectonics, International Geology Review, Vol. 52, Nos. 4-6, April-June 2010, 423-453.

Grieco, G., Rassios, A., Merlini, A. and Fantone, I., 2013. L'Aliakmon Legacy Project: un progetto internazionale per lo sviluppo geoturistico in Macedonia occidentale, Grecia, Geologia e Turismo, Atti del $5^{\circ}$ Congresso Nazionale, 116-117. 
Grieco, G., Rassios, A.E., Merlini, A. and Fantone, I., 2014. The Aliakmon Legacy: a project for geotouristic development in Western Macedonia, Greece, Bul. Shk. Gjeol. 1/2014 - Special Issue, Proceedings of XX CBGA Congress, Tirana, Albania, 24-26 September 2014, 274-277.

Grieco, G. and Merlini, M., 2012. Chromite alteration processes within Vourinos Ophiolite, Int. J. Earth Sci. (Geol. Rundsch.), 101, 1523-1533.

Heezen, B.C., Tharp, M. and Ewing, M., 1959. The Floors of the Oceans. I. The North Atlantic, The Geological Society of America Special Paper, 65, 122 pp.

Moores, E.M., 1969. Petrology and structure of the Vourinos ophiolitic complex of northern Greece: Geological Society of America Special Paper, 118, 74 pp.

Moores, E.M., 2003. A personal history of the ophiolite concept, Geological Society of America Special Paper, 373, 17-29.

Myhill, R., 2008. Metamorphic Development beneath the Pindos-Vourinos-Ophiolite Slab, MSc Thesis Cambridge University, $125 \mathrm{pp}$.

Myhill, R., 2011. Constraints on the evolution of the Mesohellenic Ophiolite from subophiolitic metamorphic rocks. In: Wakabayashi, I. and Dilek, Y., eds, Mélanges: Processes of Formation and Societal Signficance, Geol. Soc. Am. Spec. Paper, 480, 75-94.

Naylor, M., and Harle, T., 1976. Palaeogeographic significance of rocks and structures Beneath the Vourinos ophiolite, northern Greece, Journal of the Geological Society, London, 132, 667-676.

Rassios, A., 2004. A Geologist's Guide to West Macedonia, Greece, The Grevena Development Agency, Grevena, 128 pp.

Rassios, A. and Aliakmon River Legacy Project Participants, 2007. Rocks in the Wild, I.G.M.E. Athens, Greece. 128 pp.

Rassios, A., Smith, A. and Kostopoulos, D., 2008. GUIDEBOOK Ophiolites 2008: Link between the Mesohellenic Ophiolites and Pelagonian Margin, West Thessaly and West Macedonia, Greece, Inst. Of Geology and Mineral Research, 88 pp. Reprinted in Virtual Explorer, 2009. http://www.virtualexplorer.com.au/journal/2009/34/.

Spray, J.G. and Roddick, J.C., 1980. Petrology and 40Ar/39Ar geochronology of some Hellenic sub-ophiolitic metamorphic rocks, Contributions to Mineralogy and Petrology, 72, 43-55.

Wright, L., 1986. The effect of deformation on the Vourinos ophiolite. In: Rassios, A., Roberts, S. and Vacondios, I., eds., The Application of a Multidisciplinary Concept for Chromite Exploration in the Vourinos Complex (N. Greece), Inst. Mining and Mineral Exploration, Athens, 156-216.

Zimmerman, J., 1968. Structure and Petrology of Rocks Underlying the Vourinos Ophiolitic Complex, Northern Greece, PhD Thesis, Princeton University, 98 pp.

Zimmerman, J., 1969. The Vourinos Complex-an allochthonous alpine ophiolite in Northern Greece, Abstr. Geol. Soc. Am. Ann. Mtg., 245.

Zimmerman, J., 1972. Emplacement of the Vourinos ophiolitic complex, northern Greece, Memoir of the Geological Society of America, 132, 225-239.

Zlatkin, O., Avigad, D. and Gerdes, A., 2014. Peri-Amazonian provenance of the Proto Pelagonian basement (Greece), from zircon U-Pb geochronology and Lu-Hf isotopic geochemistry, Lithos, 184-187, 379-392. 